\title{
Macroinvertebrates of inlets and outlets of the Tatra Mountain lakes (Slovakia)
}

\author{
Ladislav Hamerlík, Ferdinand Šporka \& Zuzana ZaŤovičová \\ Institute of Zoology, Slovak Academy of Sciences, Dúbravská cesta 9, SK-84506 Bratislava, Slovakia; \\ e-mail: ladislav.hamerlik@savba.sk
}

\begin{abstract}
The composition of invertebrates of inlets and outlets of selected West Tatra and High Tatra lakes (Slovakia, $49^{\circ} 10^{\prime} \mathrm{N}, 20^{\circ} 00^{\prime} \mathrm{E}$ ) was analyzed. Twenty-seven sampling sites representing 11 inlets and 16 outlets of 19 mountain lakes were investigated. In total, 10,692 aquatic invertebrates from 27 samples were sorted, 7,314 from inlets and 3,378 from outlets. Altogether, 110 zoobenthic taxa ( 81 in inlets and 85 in outlets) belonging to 12 higher taxonomic groups were identified. The most constant benthic groups found both in inlets and outlets, at more than half of all sites, were Oligochaeta (93\% of all sites), Chironomidae (78\%), Trichoptera (63\%), Plecoptera (59\%) and Turbellaria (56\%). The most abundant groups were Chironomidae (4,697 ind.), Oligochaeta (2,473 ind.) and Turbellaria (2,236 ind.). No statistically significant differences were found between the benthic communities of inlets and outlets. On the contrary, significant differences $(P$ $<0.05)$ were found in some parameters of benthic communities of inlets situated in different altitudes $(<1800 \mathrm{~m}$ a.s.l., 1800-2000 m a.s.l., > $2000 \mathrm{~m}$ a.s.l), outlets of different altitudes, and finally, outlets of lakes with different areas $(<5$ ha and $\geq 5 \mathrm{ha}$ ). Cluster analysis relatively clearly separated outlets of subalpine lakes from the alpine lakes. Also, outlets of lakes with the lowest $\mathrm{pH}$ were separated from the other sites. In the case of inlets, West Tatra sites were separated from the High Tatra sites.
\end{abstract}

Key words: Zoobenthos, invertebrates, inlet, outlet, mountain lakes, Tatra Mountains, Slovakia.

\section{Introduction}

In the Tatra Mountains (Mts) - the highest mountains of both Slovakia and the Carpathian mountain range - there are about 120 lakes of glacial origin, representing more than $90 \%$ of all lakes in Slovakia. VEJDOVsKÝ (1884) and DADAY (1897) started research of macrozoobenthos of Tatra lakes at the end of the $19^{\text {th }}$ century. Up to the present, numerous authors have studied the benthos of these lakes from different points of view (KoWALEWSKI, 1914; ZAVŘEL, 1935a, b, 1937a, b; ZAVŘEL \& PAGAST, 1935; HRABĚ, 1939, 1940, 1942; GOWIN \& ZAV̌̌EL, 1944; ČERNOSVITOV, 1930; OBR, 1955; ERTLOVÁ, 1964, 1987; JURIŠ et al., 1965; ŠPORKA, 1984, 1992a, b; KRNO et al., 1985, 2006; KRNO, 1988a, b, 1991a, b; VRANOVSKÝ et al., 1994; BITUŠÍK, 1996, 2004; KowNACKI et al., 2000; BitušíK et al., 2003, 2006; ZAŤovičovÁ, 2002, 2003; TÁtosová \& STUCHLÍK, 2003; HAMERLÍK, 2004; BulánKovÁ \& ZAŤOvičovÁ, 2006). Recently, the High Tatra lakes were investigated during multilateral projects supported by the EU, as reviewed in ŠTEFKOVÁ \& ŠPORKA (2001). However, only few works have focused on inlets and outlets of the Tatra lakes (KRNO, 1988b, 1991a; KownACKI et al., 1997). The fauna of other European lakes outlets has been extensively studied by MüLler (1954), ILLIES (1956), ULFSTRAND (1968) and RiCHARDSON \& MACKAY (1991). These last authors have also reviewed papers which have investigated the fauna of lake outlets.

This work is part of a larger investigation focused primarily on the littoral, profundal and pelagial communities of macroinvertebrates, paleolimnology, chemical and physical parameters of the Tatra lakes, as well as characteristics of soils in their catchments. The aim of the present study is to compare lake inlets and outlets based on their invertebrate communities. Differences between inlets and outlets of different altitudes and outlets of different lake areas were also investigated.

\section{Material and methods}

Study area

The study area is located in the High Tatra and West Tatra Mts (West Carpathians) within the Tatra National Park (N Slovakia, $49^{\circ} 10^{\prime} \mathrm{N}, 20^{\circ} 00^{\prime} \mathrm{E}$ ). The dominant bedrock of the Tatra Mts is granodiorite, thus the water of these lakes is extremely poor in inorganic and organic components and has very weak neutralizing capacity. Altogether, 11 inlets and 16 outlets of 19 lakes were investigated. The altitude of the studied lakes ranges from 1674 to $2055 \mathrm{~m}$ a.s.l. and their surface areas from 0.1 to 18.2 ha. All of the lakes are situated 
Table 1. List of the studied lakes and their basic parameters (GREGOR \& PACL, 2005). Temperatures represent current values measured in the littoral in September 2000.

\begin{tabular}{|c|c|c|c|c|c|c|c|c|}
\hline Lake name & Lake code & $\begin{array}{l}\text { Altitude } \\
\text { (m a.s.l.) }\end{array}$ & $\begin{array}{l}\text { Lake area } \\
\qquad\left(\mathrm{m}^{2}\right)\end{array}$ & $\begin{array}{l}\text { Depth } \\
(\mathrm{m})\end{array}$ & $\begin{array}{c}\text { Temp. } \\
{ }^{\circ} \mathrm{C}\end{array}$ & $\begin{array}{c}\text { Inlet } \\
\text { presence }\end{array}$ & $\begin{array}{c}\text { Outlet } \\
\text { presence }\end{array}$ & Seepage \\
\hline Pusté pleso & PUSTE & 2056 & 11890 & 6.6 & 6.6 & 0 & 1 & 0 \\
\hline Vel'ké spišské pleso & VESPIS & 2013 & 28700 & 10.1 & 6.4 & 1 & 1 & 0 \\
\hline Prostredné spišské pleso & PRSPIS & 2010 & 18880 & 4.7 & 7.0 & 0 & 1 & 0 \\
\hline Prostredné sivé pleso & PRSIVE & 2013 & 10810 & 4.8 & 6.5 & 1 & 1 & 0 \\
\hline Vyšné zbojnícke pleso & VYZBOJ & 1961.8 & 6410 & 8.3 & 6.9 & 1 & 1 & 0 \\
\hline Prostredné zbojnícke pleso & PRZBOJ & 1959.6 & 6135 & 5.3 & 7.5 & 1 & 1 & 0 \\
\hline Velké Hincovo pleso & VEHINC & 1944.8 & 200800 & 54.0 & 7.8 & 1 & 1 & 0 \\
\hline Nižné Terianske pleso & NITERI & 1940.4 & 55580 & 47.3 & 7.4 & 1 & 1 & 0 \\
\hline Malé Hincovo pleso & MAHINC & 1921.3 & 22260 & 6.4 & 7.6 & 1 & 1 & 1 \\
\hline Vyšné Satanie pliesko & SATANI & 1894 & 2010 & 3.5 & 9.5 & 0 & 1 & 0 \\
\hline Batizovské pleso & BATIZO & 1884.2 & 34775 & 10.5 & 6.0 & 0 & 1 & 0 \\
\hline Litvorové pleso & LITVOR & 1860 & 18645 & 19.1 & 4.4 & 0 & 1 & 0 \\
\hline Nižné Jamnícke pleso & NIJAMN & 1732 & 11315 & 8.2 & - & 1 & 0 & 0 \\
\hline Štvrté Roháčske pleso & HOROHA & 1719.2 & 14400 & 8.2 & 9.0 & 1 & 0 & 1 \\
\hline Vyšné Temnosmrečinské pleso & VYTEMN & 1724.8 & 55625 & 20.0 & 5.8 & 1 & 1 & 0 \\
\hline Malé Žabie javorové pleso & MAZABI & 1704.2 & 1800 & 3.1 & 5.5 & 0 & 1 & 0 \\
\hline Vyšné Žabie bielovodské pleso & VYZABI & 1699.1 & 94640 & 24.8 & 8.5 & 0 & 1 & 0 \\
\hline Vyšné Račkove pleso & VYRACK & 1696.8 & 7425 & 12.3 & 7.6 & 1 & 0 & 0 \\
\hline Nižné Temnosmrečinské pleso & NITEMN & 1677 & 117045 & 38.1 & 9.8 & 0 & 1 & 0 \\
\hline
\end{tabular}

above timberline. The dominant vegetation in their catchments is composed of shrubs of dwarf pine (Pinus mugho) up to $\sim 1800 \mathrm{~m}$ a.s.l., and alpine meadows and rocks above $\sim 1800 \mathrm{~m}$ a.s.l. Three lakes (Štvrté Roháčske pleso, Nižné Jamnícke pleso and Vyšné Račkove pleso) have only inlets, seven lakes (Vyšné Žabie bielovodské pleso, Litvorové pleso, Batizovské pleso, Malé Žabie javorové pleso, Pusté pleso, Prostredné spišské pleso and Vyšné Satanie pliesko) have only outlets. The remaining eight lakes have both inlets and outlets. Despite the fact that Nižné Temnosmrečinské pleso has both inlet and outlet, samples were taken just from the outlet, because its inlet is the same as the outlet of Vyšné Temnosmrečinské pleso which was sampled. The list of the examined lakes and their basic parameters is given in Table 1. Detailed morphometry, hydrography hydrology and the thermal regime of the observed lakes was published by GREgOR \& PACL (2005) and ŠporkA et al. (2006).

Investigated outlets and especially inlets were not uniform. Differences were obvious in flow intensity, width and depth. Inlets differed also in their length, slope and watershed size. In each case, outlets were sampled close to the lake dam (5-10 $\mathrm{m}$ from the outflow region).

\section{Biological sampling}

The field survey was carried out between 16-29 September, 2000. Altogether 11 and 16 samples were taken from inlet and outlet streams, respectively. Within each sampling site, kick samples of zoobenthos were collected using a hand net (frame $25 \times 25 \mathrm{~cm}$, mesh size $300 \mu \mathrm{m}$ ) disturbing the substrate for $5 \mathrm{~min}$. During the sampling all present substrate types were included (from soft sand to pebbles and rocks). The collected material was preserved in $4 \%$ formalin. Organisms were hand-sorted under a stereoscopic microscope, identified to the lowest possible taxonomic level and counted. The results are expressed as number of individuals collected during the 5 min of kicking. Taxa were assigned to a trophic category based on ŠPORKA (2003).

Physical and chemical parameters as well as zooplankton and phytoplankton were also studied within the same framework. These results are published by KOPÁČEK et al., (2006), SACHEROvÁ et al. (2006) and Stuchlík et al. (2006).

\section{Data analysis}

Hierarchical classification analysis was performed to find the main groups of sampling sites by PC-ORD (MCCunE \& MEFFORD, 1999). The complete linkage method and Jaccard index of similarity were used to compare 11 inlet and 16 outlet sites based on presence/absence data of 21 zoobenthic taxa with occurrence at three or more sampling sites.

One-way analysis of variance (ANOVA) was used to find significant differences between inlets and outlets. In addition, inlets and outlets situated at different altitudes $(<1800 \mathrm{~m}$ a.s.l., $1800-2000 \mathrm{~m}$ a.s.l. and $>2000$ $\mathrm{m}$ a.s.l.) and outlets of lakes with different areas $(<5$ ha, $\geq 5$ ha) were tested. The tested attributes in each case were total abundance, total number of taxa, abundance of EPT taxa (Ephemeroptera, Plecoptera and Trichoptera together), number of EPT taxa, abundance of Oligochaeta, taxa number of Oligochaeta, abundance of Chironomidae, and taxa number of Chironomidae, plus the following ratios: abundance and taxa numbers of Chironomidae/total fauna, Oligochaeta + Chironomidae/total fauna $(\mathrm{O}+\mathrm{CH} /$ total fauna $)$, permanent fauna/total fauna, and temporal fauna/total fauna. Representatives of Hydrozoa, Turbellaria, Nematoda, Oligochaeta and Hydracarina were considered to be permanent fauna. Representatives of the remaining taxonomic groups constituted temporal fauna.

Species abundance data (if transformed) were $[\log (x+$ 1)] transformed. SigmaStat 3.1 was used for these analyses and values with $P<0.05$ were considered significant.

\section{Results}

\section{Species richness and frequency}

Altogether, 10,692 specimens of aquatic invertebrates from 27 samples were sorted. In total, 110 zoobenthic taxa belonging to 12 higher taxonomic groups were 


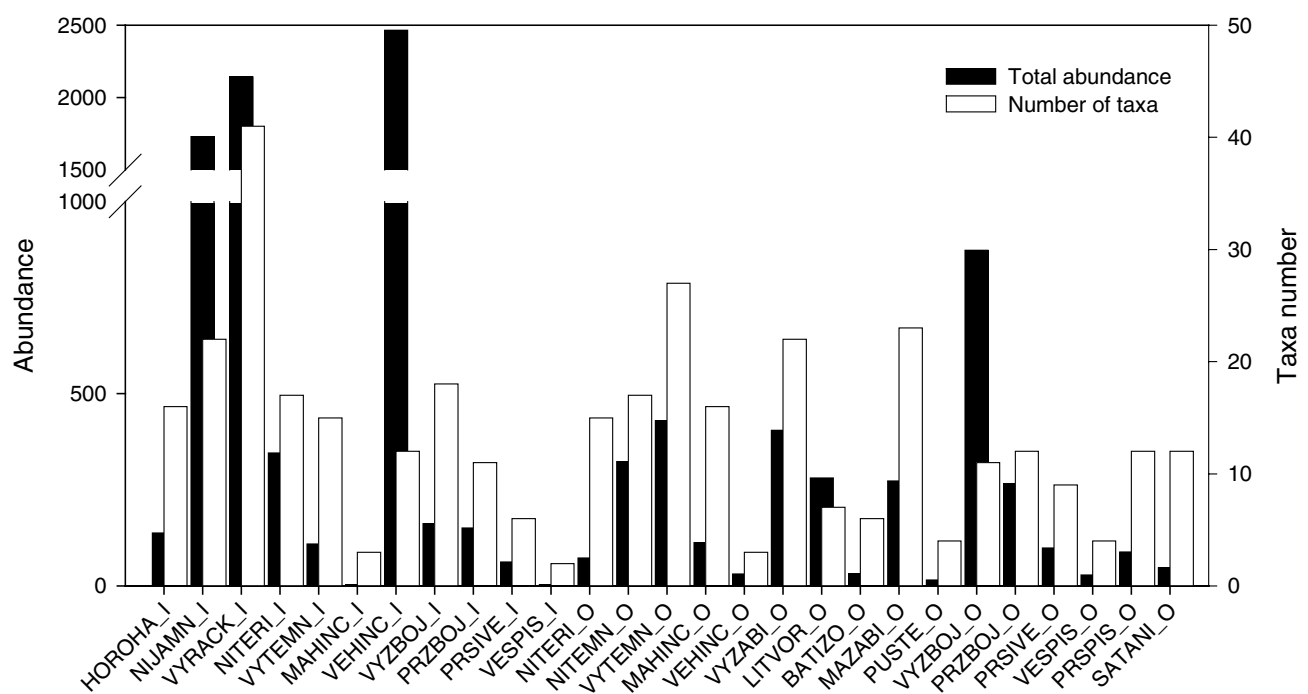

Fig. 1. Total abundance and number of taxa found at each sampling site. The left $y$-axis represents the abundance as number of total sampled individuals. The right $y$-axis represents the taxa number as number of total identified taxa in the site. I - inlets, O - outlets; for lake codes see Table 1.

identified: Hydrozoa, Turbellaria, Nematoda, Oligochaeta, Hydracarina, Ephemeroptera, Plecoptera, Heteroptera, Megaloptera, Coleoptera, Trichoptera and Diptera. The complete list of taxa and their abundance is presented in Appendix 1. Representatives of Heteroptera were found only in inlets, Hydrozoa and Megaloptera only in outlets; however, frequency and abundance of these taxa were very low. The number of taxa occurring both in inlets and outlets was 57, while 24 taxa were restricted to inlets and 28 to outlets. Besides Drusus monticola (found in 3 of 11 inlets) and Diura bicaudata (in 7 of 16 outlets), the frequency of taxa occurring only in inlets or only in outlets was very low (found max. in 2 of all sites). The major groups (occurring in more than half of all sites), were Oligochaeta (93\% of all sites), Chironomidae (78\%), Trichoptera (63\%), Plecoptera $(59 \%)$ and Turbellaria $(56 \%)$. The most abundant groups were Chironomidae (4,697 individuals), Oligochaeta (2,473 ind.) and Turbellaria (2,236 ind.). Other benthic groups were represented by less than 403 specimens. Chironomidae, with 38 taxa, represents $34 \%$ of the species richness, Trichoptera were represented by 15 taxa (13.5\%), and Plecoptera and Oligochaeta by 12 taxa each $(10.8 \%)$. The total abundance and taxa number of the 27 sampling sites are given in Fig. 1 .

Inlets were represented by 7,314 specimens of benthic invertebrates, with abundances ranging from 3 ind. (Vel'ké spišské pleso) to 2,467 ind. (Velké Hincovo pleso) per $5 \mathrm{~min}$ of sampling. The invertebrates belonged to 81 taxa; however, 49 of them occurred only at 1 of 11 sites and only 3 taxa were found in more than $50 \%$ of the inlets (Crenobia alpina, Nematoda and Nais variabilis). All 11 inlet sites contained Oligochaeta, Chironomidae were found in $9(82 \%)$ and representatives of other Diptera in 7 inlets $(63 \%)$. The predominant benthic groups at the studied sites were Chironomi- dae (3,792 ind.) followed by Turbellaria (1,741 ind.) and Oligochaeta (1,171 ind.). These 3 groups represented more than $90 \%$ of the total abundance of inlets; Chironomidae represented more than $50 \%$ of the total abundance. The most abundant species were $C$. alpina, N. variabilis, Eukiefferiella gracei gr. and Tvetenia calvescens. The greatest number of taxa was collected at Vyšné Račkove pleso (41 taxa), followed by Nižné Jamnícke pleso (22 taxa) and Vyšné zbojnícke pleso (18 taxa). The mean taxa number found in inlet sites was 15 . Frequency and abundance of the most common inlet taxa is given in Fig. 2A.

Despite the higher number of outlets (16) compared to the number of inlets (11), only 3,378 specimens of benthic invertebrates with abundances ranging from 16 ind. (Pusté pleso) to 873 ind. (Vyšné zbojnícke pleso) per sampling period were found. The collected invertebrates were classified into 85 taxa; 44 of them occurred at only 1 of all outlet sites. As with the inlets, the species composition of outlets also showed considerable variability: only 4 species were found in more than $50 \%$ of outlets (C. alpina, N. variabilis, Heterotrissocladius marcidus, Micropsectra sp.). The most frequent groups were Oligochaeta, Chironomidae, Plecoptera, Turbellaria and Ephemeroptera. Numerically, Oligochaeta dominated (1,302 ind.); however, abundances of Chironomidae (905 ind.), Turbellaria (495 ind.) and Ephemeroptera (353 ind.) were also considerable. The most abundant species were $N$. variabilis, C. alpina, Ameletus inopinatus, Microspectra sp. and $H$. marcidus. The greatest taxa number was found in outlet of Vyšné Temnosmrečinské pleso (27), followed by Malé Žabie javorové pleso (23) and Vyšné Žabie bielovodské pleso (22). The mean taxa number found in inlet sites was 13 . Frequency and abundance of the most common outlet taxa is given in Fig. 2B. 
A

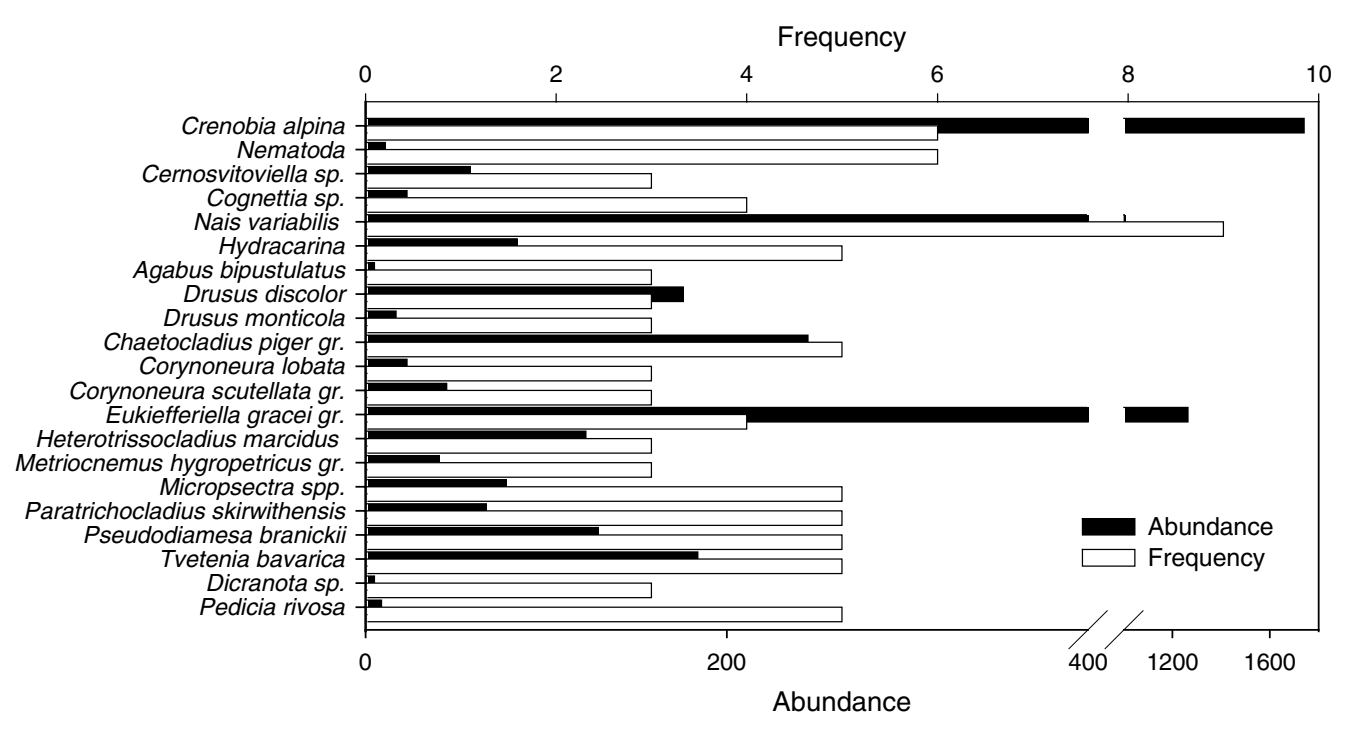

B

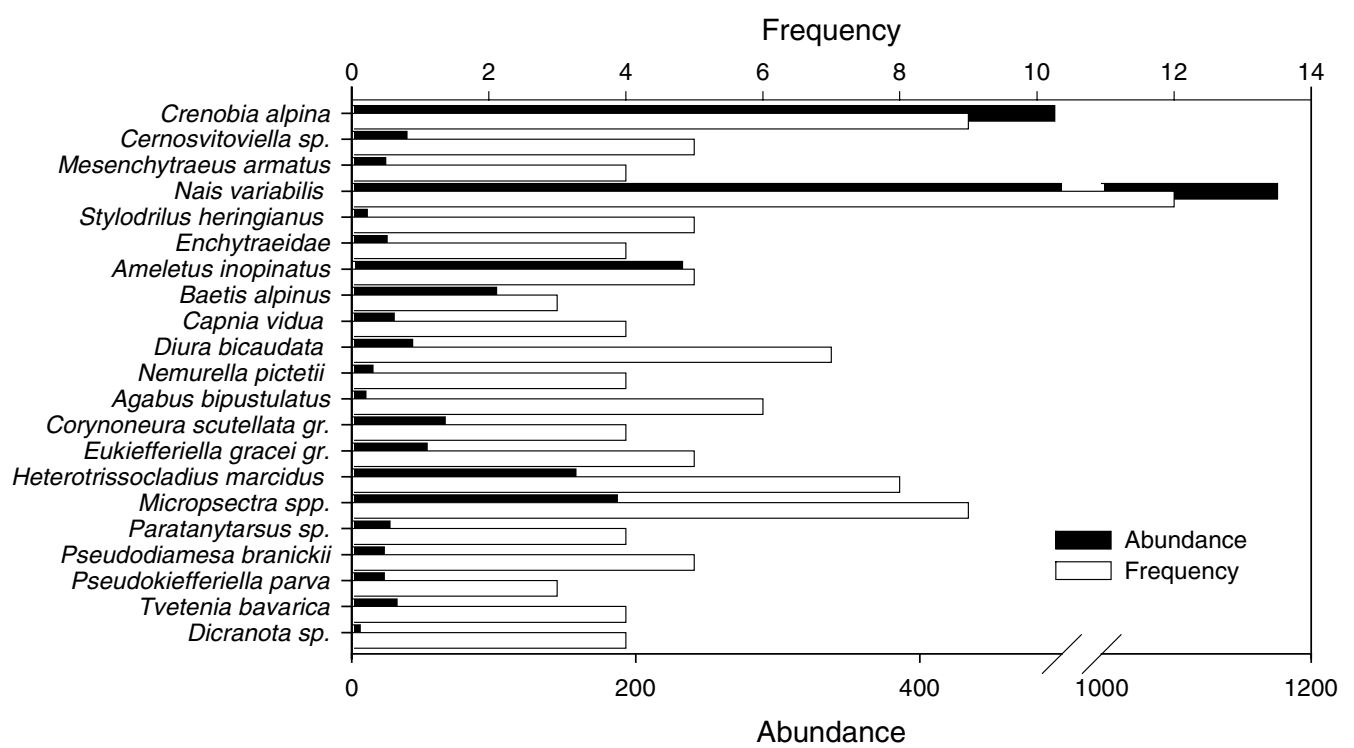

Fig. 2. The most represented macroinvertebrate taxa in inlet (A) and outlet (B) sites. The top $x$-axis represents the frequency as number of sampling sites with occurrence of the taxon. The bottom $x$-axis represents the abundance as number of total sampled individuals. Only taxa collected in three or more sites have been considered.

\section{Trophic structure}

The trophic structure of the inlet and outlet invertebrate communities is shown in Fig 3.

Scrapers $(41 \%)$ predominated in inlets, followed by collectors $(29 \%)$ and predators $(28 \%)$. Shredders $(1 \%)$ and filter feeders (1\%) represented a negligible part of the total invertebrate fauna.

In outlet sites, collectors were predominant $(43 \%)$ followed by scrapers $(29 \%)$ and predators $(25 \%)$. As in inlets, the representation of filter feeders $(1 \%)$ and shredders $(2 \%)$ was not considerable.

\section{Classification of study sites based on zoobenthic species \\ Inlets}

Cluster analysis, based on presence/absence data, separated the investigated inlets into four basic clusters (Fig. 4). The first cluster A is subdivided into two clusters. Sub-cluster A1 could be described as a group of three West Tatra lake inlets lying in the subalpine zone. Typical taxa for this sub cluster are $N$. variabilis, Chaetocladius piger gr., Corynoneura lobata, Micropsectra sp., Dicranota sp. and Pedicia rivosa. Sub-cluster 
A2 consists of inlets of two alpine lakes situated in the same valley at almost the same altitude. Their common taxa are C. alpina, N. variabilis, Hydracarina, Agabus bipustulatus, Corynoneura scutellata gr., Eukiefferiella gracei gr., H. marcidus and Micropsectra sp. Generally, cluster A contains inlets with the highest taxa number (13-9); Micropsectra spp. occurs only in sites of this cluster.

The second cluster B contains inlets of lakes with large area ( $>5$ ha) and could be divided into two subclusters: B1 includes two alpine lake inlets; sub-cluster B1 consists of one inlet of a subalpine lake. Inlet sites of cluster B typically have relatively high taxa number (8-9) and the occurrence of Nematoda and Tvetenia bavarica.

The third cluster $\mathrm{C}$ consists of two very similar alpine lake inlets, characterized by very low species richness (the lowest from the investigated inlet sites). The only species found was $N$. variabilis.

The fourth cluster D consists of one separated alpine lake inlet. As with cluster C, low taxa number was typical for this site (only oligochetes Cernosvitoviella sp. and Cognettia sp. were present). Clusters C and $\mathrm{D}$, which showed the highest dissimilarity to the other sites, contain two inlet sites with the highest altitude (> $2000 \mathrm{~m}$ a.s.l.) and with the lowest species richness among the investigated sites.

\section{Outlets}

16 outlet sites were divided into five basic clusters based on presence/absence data (Fig. 5). The first cluster A contains 2 sub-clusters: A1 includes three alpine lake outlets with relatively high taxa number (12-
A

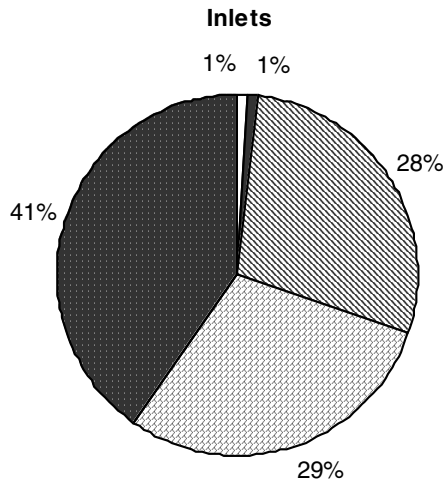

B

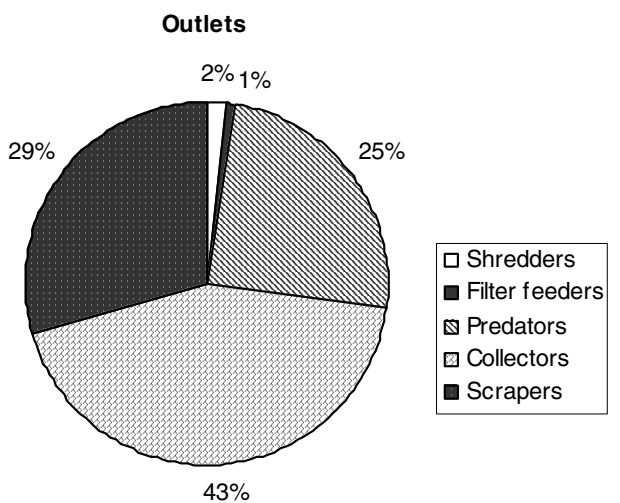

Fig. 3. Representation of functional feeding groups in inlets (A) and outlets (B).

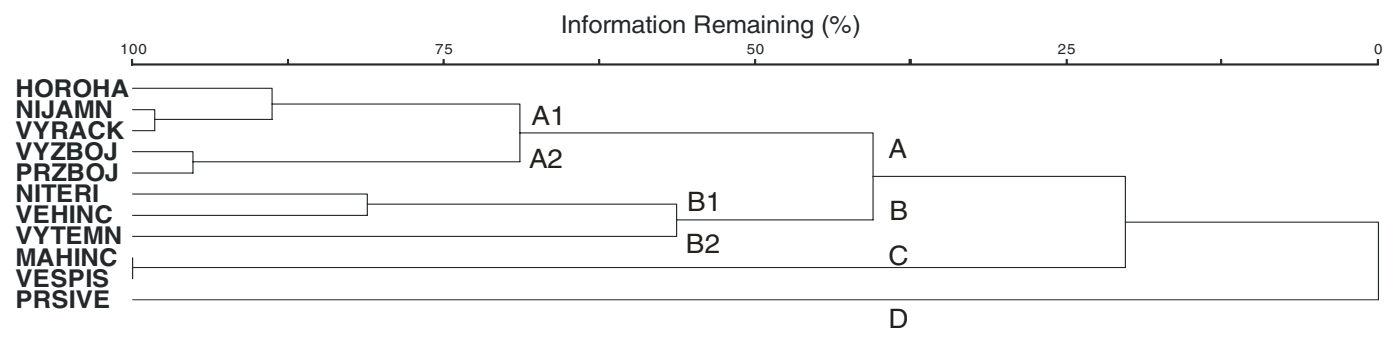

Fig. 4. Hierarchical cluster analysis of inlet sites based on presence/absence data of 21 zoobenthos taxa. For lake codes see Table 1.

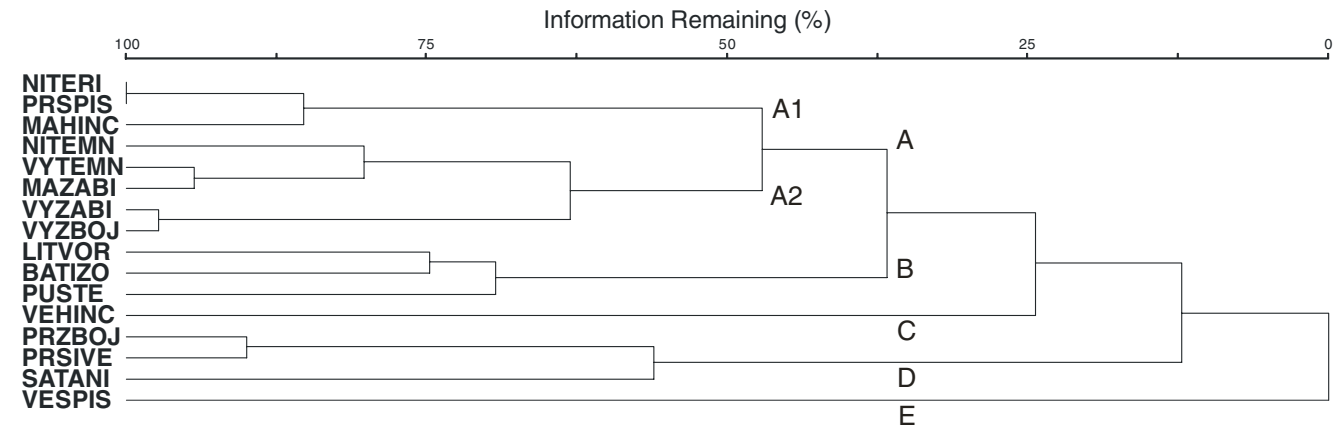

Fig. 5. Hierarchical cluster analysis of outlet sites based on presence/absence data of 21 zoobenthos taxa. For lake codes see Table 1. 
A

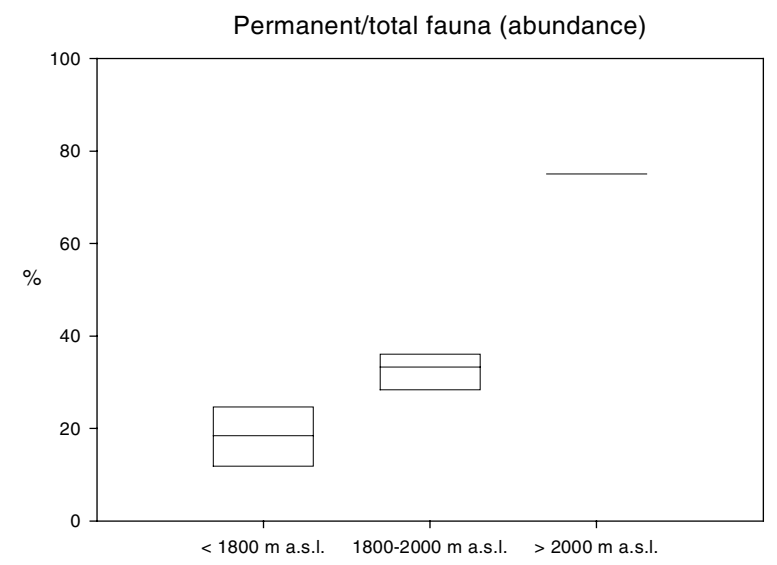

B

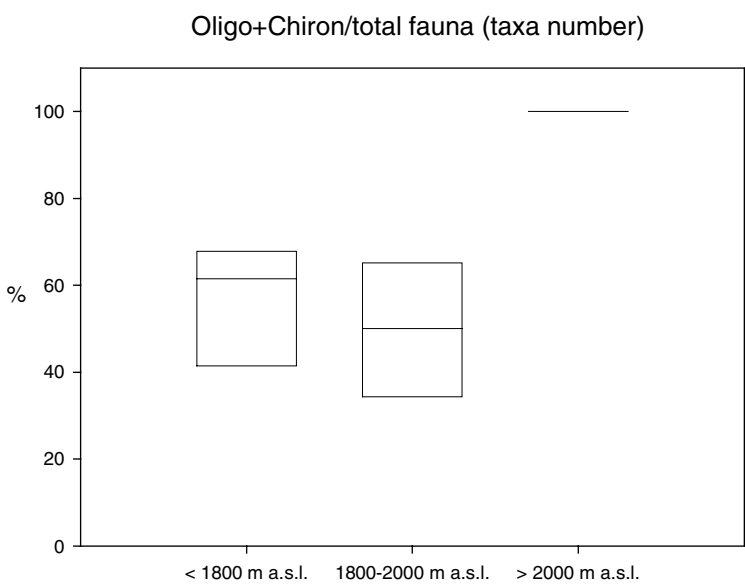

C

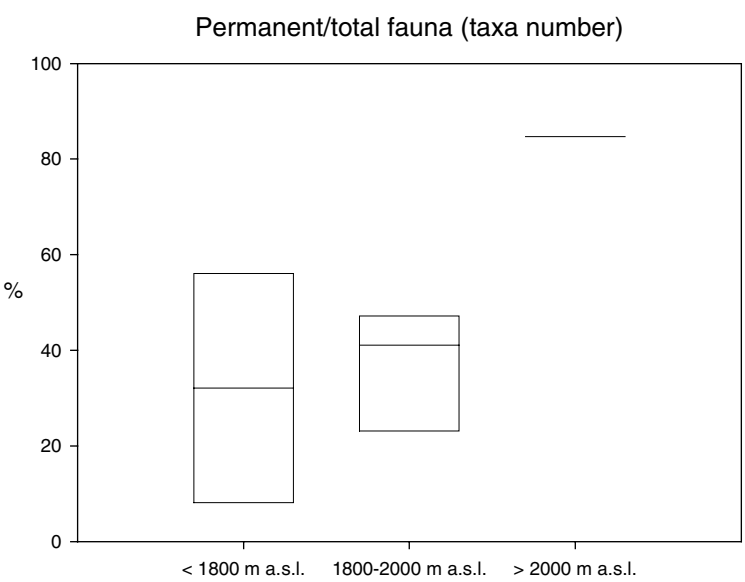

Fig. 6. Box \& Whisker-plots showing the variability of statistically significant attributes of inlets situated at different altitudes $(P<0.05)$. A - permanent/total fauna (abundance), B - Oligochaeta + Chironomidae/total fauna (taxa number), C permanent/total fauna (taxa number).

16). Sub-cluster A2 consists of five outlet sites with high number of taxa (11-27) and the highest abun- dance of the outlet sites. Four of them are situated in the subalpine zone, whereas one lake lies in the alpine zone. Furthermore, three lakes have an area greater than 5 ha. For the whole cluster A, the presence of $N$. variabilis and Micropsectra sp. was characteristic.

The second cluster B is characterised by low species richness (4 to 7 taxa) and the absence of common taxa such as D. bicaudata, A. bipustulatus, H. marcidus and Micropsectra sp. The only taxon occurring in all three sites was $N$. variabilis. This cluster consists of three alpine lakes; two of them (BATIZ and LITVOR) are situated at almost identical altitude.

Cluster $\mathrm{C}$ consists of one separated site, the outlet of an alpine lake. This was the only site where Baetis alpinus and Capnia vidua occurred together.

The fourth cluster D could be described as a group of three outlets of small (area $<1$ ha) alpine lakes. Two of them (PRSIVE and SATANI), have the lowest $\mathrm{pH}$ of the investigated lakes $(\mathrm{pH} 4.87$ and 5.76). The typical taxa of these sites were Cernosvitoviella sp. and H. marcidus.

Cluster E is represented by a single site, the outlet of a lake which lies in the alpine zone. Pseudodiamesa branickii and Pseudokiefferiella parva occurred in this site.

Both clusters $\mathrm{C}$ and $\mathrm{E}$ are characterised by very low taxa numbers (3 and 4) and also the absence of common taxa as in the case of cluster B. Cluster E is the least similar to other clusters.

\section{Testing the differences between sites}

No statistically significant differences were found between the benthic communities of inlets and outlets for those parameters tested.

On the contrary, significant differences $(P<0.05)$ were found among benthic communities of inlets situated in different altitude zones, and for outlets of different altitudes. In the case of inlets these parameters were the ratio of the taxa number of permanent/total fauna, $\mathrm{O}+\mathrm{CH} /$ total fauna (taxa number), and the ratio of the abundance of permanent/total fauna (Fig. 6).

Outlets differed significantly in total number of taxa, number of EPT taxa, transformed total abundance, taxa number of permanent fauna and taxa number of temporal fauna (Fig. 7).

The only attribute in which lakes with different areas $(<5$ ha and $\geq 5$ ha) significantly differed was the number of EPT taxa (Fig. 8).

While the subalpine lake outlets differed from the alpine lake outlets, differences between alpine lake outlets situated at 1800-2000 $\mathrm{m}$ and above $2000 \mathrm{~m}$ a.s.l. were not significant.

Inlets situated above $2000 \mathrm{~m}$ a.s.l significantly differed from both inlets of lakes situated in the subalpine zone and at 1800-2000 $\mathrm{m}$ a.s.l. No significant differences were found between inlets of subalpine lakes and alpine lakes situated at 1800-2000 m a.s.l. 
A

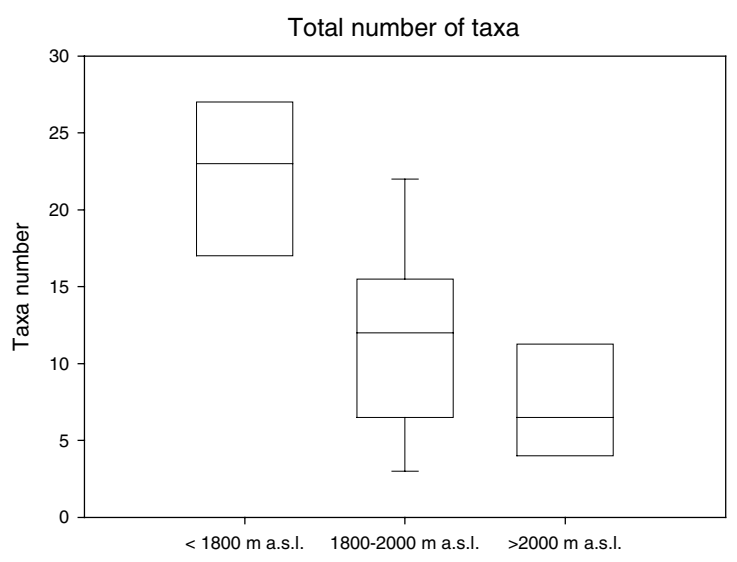

B

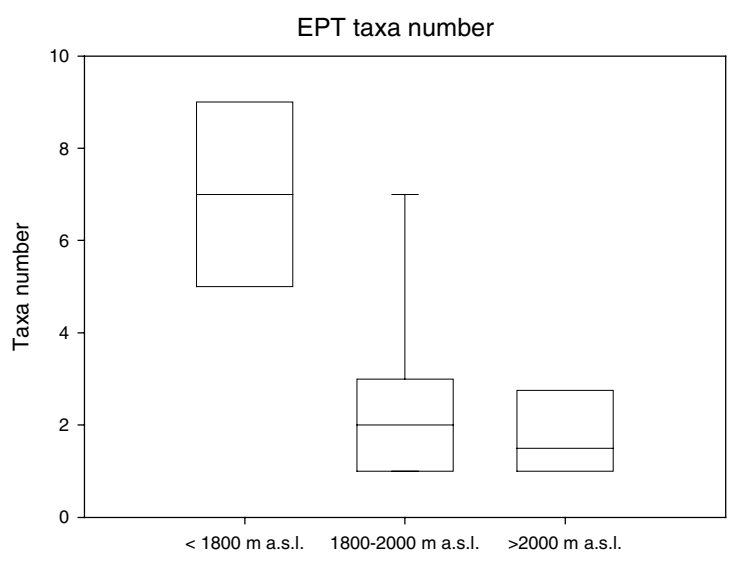

C

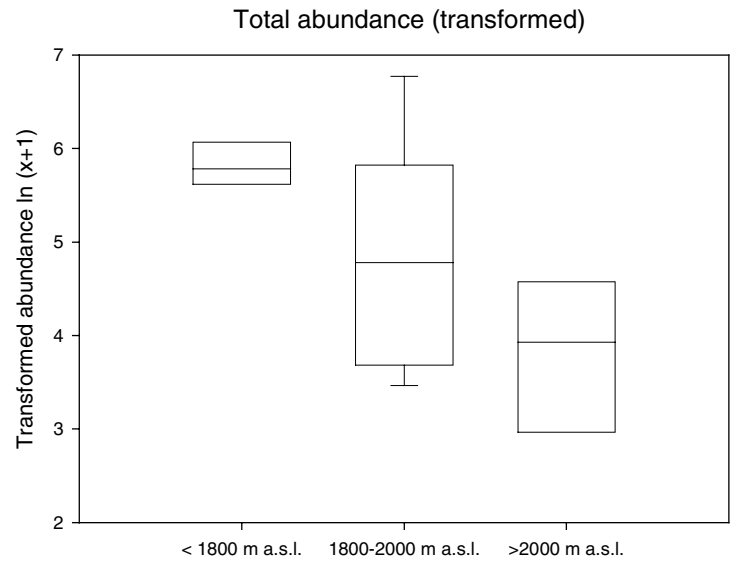

\section{Discussion}

The most important feeding groups of the studied Tatra lake outlets were collectors and scrapers. Filter-feeding invertebrates represented only a marginal part of the

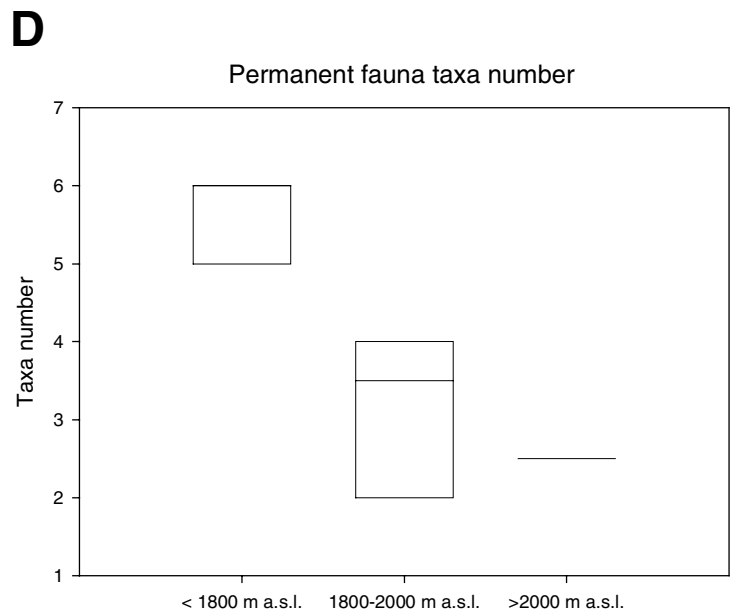

$\mathbf{E}$

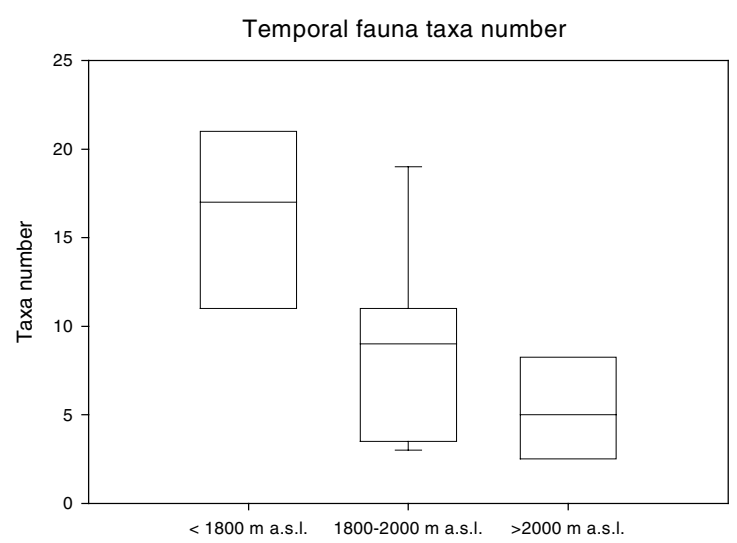

Fig. 7. Box \& Whisker-plots showing the variability of statistically significant attributes of outlets situated at different altitudes $(P<0.05)$. A - total number of taxa, B - number of EPT taxa (Ephemeroptera + Plecoptera + Trichoptera), C total abundance (transformed), D - taxa number of permanent fauna, $\mathrm{E}$ - taxa number of temporal fauna.

community. However, in other studies focused on lake outlets, the predominant invertebrate groups are filterfeeders such as Simuliidae, net spinning Trichoptera, bivalves and other filter-feeder invertebrates (MÜLLER, 1954; Illies, 1956; Ulfstrand, 1968; RICHARDSON 


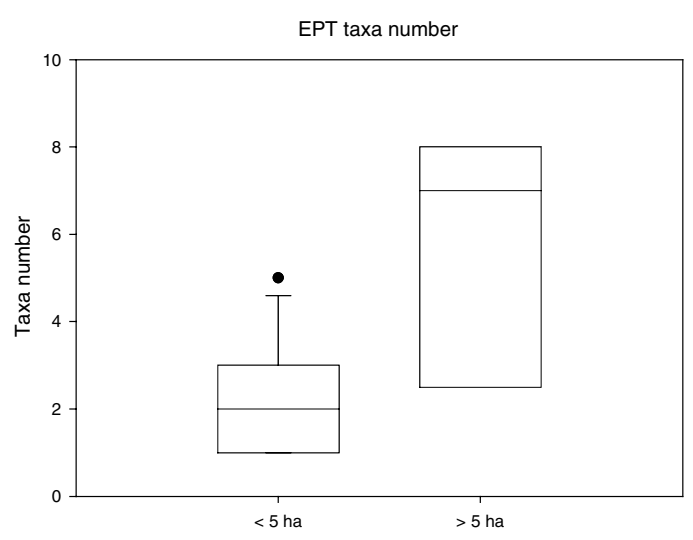

Fig. 8. Box \& Whisker-plots showing the variability of statistically significant attribute of outlets of lakes with different area $(P<0.05)$, the number of EPT taxa.

\& MACKAY, 1991). It could be supposed that the different trophic structure in the Tatra lakes is caused by the low amount of seston flowing out from these extremely oligotrophic lakes. However, the amount of seston in the outflow of Tatra lakes has not been measured.

KownACKI et al. (1997) also recognized that the community structure of Tatra lake outlets only partly corresponded with the established "lake outlet community scheme". In June, these authors found filterfeeding invertebrates (Prosimulium sp.) as the predominant group; however, in the following months the proportion of Simuliidae decreased. Starting in July, scrapers, mainly Nais variabilis, were the predominant group in the outlets (KowNACKI et al., 1997). HRABĚ (1939) found $N$. variabilis as the dominant taxon in the littoral of Tatra lakes. During the present study, the most frequent taxon was $N$. variabilis both in inlet and outlet sites; moreover, it was the second most abundant macroinvertebrate taxon in inlets (after Crenobia alpina) and the most abundant one in outlets. Also, the collector Heterotissocladius marcidus belonged to the most frequent and abundant species in sampled outlets. H. marcidus was found in all of the studied lakes and it is probably the most common chironomid of the Tatra lakes. (cf. BiTuŠík et al., 2006).

The classification of lake outlets based on zoobenthos taxa corresponded well with the Tatra lake typology based on physico-chemical features and macrozoobenthos (KRNO et al., 1985, 2006) and chironomids (BITUŠÍK et al., 2003, 2006).

According to KRNo et al. (2006) macroinvertebrate assemblages in the littoral of the Tatra lakes are affected mainly by $\mathrm{pH}$ (influenced by concentrations of $\mathrm{Ca}, \mathrm{Mg}$, alkalinity etc.) and the temperature regime of lake water (influenced by altitude and geographical orientation). Also, duration of ice cover, lake area, amount of total phosphorus and organic carbon, and the occurrence of fish play significant roles in taxonomic composition of littoral zoobenthos. These authors classified Tatra lakes into five classes based on littoral benthos and assigned typical taxa for each class: strongly acidified, alpine acidified, alpine non-acidified, subalpine acidified and subalpine non-acidified lakes. Diura bicaudata was a typical species in the littoral of subalpine lakes (KRNO et al., 2006). However, in the present study the occurrence of D. bicaudata was not restricted to the subalpine zone and it was frequent also in alpine lake outlets. KRNO et al. (2006) considered Sialis lutaria and Limnephilus coenosus typical inhabitants in the littoral of strongly acidified lakes. The same species occurred also in outlets of acidified Vyšné Satanie pliesko; moreover, S. lutaria was found only in this lake. Similarly to the situation in the littoral (KRNO et al., 2006), Arcynopteryx compacta and Haplotaxis gordioides occurred only in inlets and outlets of non-acidified alpine lakes.

BiTUŠík et al. (2006) - similarly to KRNO et al. (2006) - considered altitude, $\mathrm{Ca}^{2+}$ and $\mathrm{Mg}^{2+}$ concentrations, total phosphorus, total nitrogen and $\mathrm{pH}$ to be the most important environmental variables determining taxonomic composition of chironomids in lakes. In their study, the lake area (as the only parameter connected with lake morphometry) was significantly correlated with taxa richness. BITUŠín et al. (2006) distinguished four lake types based on the chironomid assemblages of 22 Tatra lakes: subalpine, alpine, high alpine and acidified (they have specific taxonomic composition without respect to differences in altitude). In this study, cluster analysis relatively clearly separated outlets of subalpine lakes from those of the alpine lakes. Also, lakes with the lowest $\mathrm{pH}$ were separated from the other sites. It can be supposed, that the acidification status of the lake influenced the invertebrate communities of the outlet. Zalutschia tatrica seemed to be a reliable indicator of acid conditions in the Tatra lakes (BiTUŠÍK et al., 2006; HAMERLíK, 2004; KRNO et al., 2006). The only site in which $Z$. tatrica occurred was the outlet of acidified Vyšné Satanie pliesko.

According to KownACKI et al. (1997) the seasonality of water flow is an important factor which affects the development of the outlet communities of Tatra lakes. In this region, the outlets freeze in late autumn and winter, and species which are not adapted to such conditions and those with a one-year life cycle die.

As inlets and outlets are running waters, the distribution of their invertebrate communities is affected by additional factors as substrate particle size, organic matter deposition, water depth, current velocity and the presence of mosses (MALMQVIST et al., 1999; Lencioni \& Rossaro, 2005). Current velocity influences other environmental parameters like substrate particles, deposition of silt, transport of detritus, and is necessary for respiration of organisms (LENCIONI \& Rossaro, 2005). However, some authors consider that current velocity plays a secondary role, while substrate-detritus interaction is the main factor influencing insect microdistribution (RABENI \& MINSHALL, 1977). 
It is a known fact that there is a relationship between species diversity and lake area. As mentioned above, BiTušík et al. (2006) found significant correlation between lake area and taxa richness of chironomids. The invertebrate structure of outlets also seems to be influenced by the lake area. In number of EPT taxa there were significant differences between lakes of different surface area. Outlets of lakes with area 5 ha and more were colonised by more EPT taxa than outlets of smaller lakes.

It is interesting that metrics in which zoobenthic assemblages differed were different in inlets and outlets. Inlets of lakes situated above $2000 \mathrm{~m}$ a.s.l. significantly differed in proportion of the permanent fauna, which was about $80 \%$ both in taxa number and abundance. All taxa found in these sites belonged to Oligochaeta and Chironomidae.

Outlets of subalpine lakes differed from the alpine ones in terms of analysed parameters related to taxa number and abundance. Subalpine outlets were more diverse (totally, but also in EPT taxa, and temporal and permanent fauna taxa numbers) and had higher total abundance when compared to alpine lakes.

This paper is the result of research which recorded zoobenthic assemblages within a relatively short period of time. However, in different seasons, hydrological and physico-chemical features vary and different invertebrate communities may be found in the same microhabitats. Therefore, further studies are needed to find out the exact pattern of inlet and outlet invertebrate communities of Tatra lakes due to high habitat heterogeneity and seasonality.

\section{Acknowledgements}

We acknowledge the field assistance provided by the colleagues and students of the Slovak Academy of Sciences, Comenius University, Technical University of Zvolen and Charles University, Prague. The identification of Diptera (excl. Chironomidae, Simuliidae) by E. BulÁnkovÁ, Ephemeroptera by T. DERKA, Simuliidae by D. ILlÉŠOVÁ and Plecoptera by I. KRNO is greatly acknowledged. We are also grateful to the technical stuff for sorting the material. This study has been carried out as a part of the project EMERGE EVK-CT1999-00032.

\section{References}

BituŠík, P. 1996. Biologické hodnotenie vybraných plies v Západných Tatrách na základe mediálnych spoločenstiev pakomárov (Diptera: Chironomidae), pp. 175-180. In: MIDRIAK, R. (ed.) Biosférické rezervácie na Slovensku, Proc. Conf., Zvolen.

Bitušŕk, P. 2004. Chironomids (Diptera, Chironomidae) of the mountain lakes in the Tatra Mts. (Slovakia). A review, pp. 25-33. In: BituŠ́́k, P. (ed.) Dipterologica Bohemoslovaca, Acta Fac. Ecol., Zvolen 12, Suppl. 1.

Bitušík, P., Kološta, P., Hubková, M. \& Némethová, D. 2003. Typológia tatranských jazier na základe zoskupení pakomárov (Diptera: Chironomidae). Acta Fac. Ecol., Zvolen 10, Suppl. 1: 197-200.
Bituš́í, P., Svitok, M., Kološta, P. \& Hubková, M. 2006. Classification of the Tatra Mountain lakes (Slovakia) using chironomids (Diptera, Chironomidae). Biologia, Bratislava 61, Suppl. 18: S191-S201.

BulÁNKOVÁ, E. \& ZAT̃OVIČOVÁ, Z. 2006. Preimaginal stages of Diptera (excluding Chironomidae and Simuliidae) of mountain lakes, their inlets and outlets in the Tatra Mountains (Slovakia). Biologia, Bratislava 61, Suppl. 18: S185-S190.

Černosvitov, L. 1930. Příspěvky k poznání fauny tatranských Oligochaetů. Věst. Král. Čes. Spol. Nauk, Tr. 2: 1-8.

DADAY, E. 1897. Beiträge zur Kenntnis der Microfauna der Tatra-Seen. Természetrajzi Füzetek 20: 149-196.

Ertlová, E. 1964. Príspevok k poznaniu zoobentosu Popradského plesa. Biológia, Bratislava 19: 666-674.

Ertlová, E. 1987. Chironomids (Chironomidae, Diptera) of the Littoral of the Selected Lakes in the High Tatras. Acta Fac. Rerum Nat. Univ. Comenianae, Zool. 29: 53-66.

Gowin, F. \& Zavřel, J. 1944. Nový Procladius z Vysokých Tater. Procladius tatrensis Gow. n. sp. Entomol. Listy 7: 8790.

Gregor, V. \& PACL, J. 2005. Hydrológia tatranských jazier. Hydrology of the Tatra mountain lakes. Acta Hydrologica Slovaca 6 (1): 161-187.

HAMERLÍK, L. 2004. Chironomids (Diptera: Chironomidae) of the littoral zone of some lakes in the High Tatra Mts. (Slovakia), pp. 49-55. In: Bitušík, P. (ed.) Dipterologica Bohemoslovaca, Acta Fac. Ecol., Zvolen 12, Suppl. 1.

HrabĚ, S. 1939. Vodní Oligochaeta z Vysokých Tater. Věst. Česk. Zool. Spol. 6-7: 209-236.

HRABĚ, S. 1940. Bentická zvířena tatranských jezer. Sborník Klubu Přírodověd. v Brně 22: 1-13.

HrABĚ, S. 1942. O bentické zvířene ve Vysokých Tatrách. Physiograph. Slov., Čas. Slov. Uč. Spol. 8: 124-177.

ILliES, J. 1956. Seeausfluß - Biozönosen lappländischer Waldbäche. Entomol. Tidskr. 77: 138-153.

Juriš, Š., Ertl, M., Ertlová, E., \& Vranovský, M. 1965. Niektoré poznatky z hydrobiologického výskumu Popradského plesa. Zborník TANAP 8: 33-44.

KopÁČek J., Stuchlík, E. \& HARdekopf, D. 2006. Chemical composition of the Tatra Mountain lakes: Recovery from acidification. Biologia, Bratislava 61, Suppl. 18: S21-S33.

KowAlewski, M. 1914. Materialy do fauny polskich skaposzczetow wodnych (Oligochaeta aquatica). II. Spraw. Kom. Fizjogr., Krakow 48: 134-243.

Kownacki, A., Dumnicka, E., Galas, J., Kawecka, B. \& WoJTAN, K. 1997. Ecological characteristics of a high mountain lake-outlet stream (Tatra Mts, Poland). Arch. Hydrobiol. 139: $113-128$.

Kownacki, A., Galas, J., Dumnicka, E. \& Mielewczyk, S. 2000. Invertebrate communities in permanent and temporary high mountain lakes (Tatra Mts.). Ann. Limnol. 36: 181-188.

KRno, I. 1988a. Makrozoobentos litorálu Tatranských jazier. Zborník TANAP 28: 235-250.

KRnO, I. 1988b. Podenky (Ephemeroptera) a pošvatky (Plecoptera) vybraných jazier TANAP-u, ich prítokov a odtokov. Zborník TANAP 28: 217-234.

KRNO, I. 1991a. Makrozoobentos litorálu jazier Západných Tatier a ich odtokov. Zborník TANAP 31: 217-227.

KRNO, I. 1991b. Macrozoobenthos of the Tatra lakes littoral (the High Tatras) and its affection by acidification. Biológia, Bratislava 46: 495-496.

Krno, I., Ertlová, E., TomajkA, J. \& ŠporkA, F. 1985. Klasifikácia vybraných tatranských plies na základe významnejších abiotických a biotických faktorov, pp. 220-224. In: Zborník prednášok zo VII. CSLS, Nitra.

Krno, I., Šporka, F., Bituš́í, P., Galas, J., Hamerlík, L. \& ZAŤOVIČOVÁ, Z. 2006. Littoral benthic macroinvertebrates of mountain lakes in the Tatra Mountains (Slovakia, Poland). Biologia, Bratislava 61, Suppl. 18: S147-S166.

Lencioni, V. \& Rossaro, B. 2005. Microdistribution of chironomids (Diptera: Chironomidae) in Alpine streams: an autoecological perspective. Hydrobiologia 533: 61-76. 
Malmqvist, B., Zhang, Y. \& Adler, P.H. 1999. Diversity, distribution and larval habitats of North Swedish blackflies (Diptera: Simuliidae). Freshwater Biol. 42: 301-314.

MCCune, B. \& Mefford, M.J. 1999. PC-ORD. Multivariete Analysis of Ecological Data, Version 4. MjM Software Design, Glenedech Beach, Oregon, USA.

MÚller, K. 1954. Faunistisch-ökologische Untersuchungen in nordschwedischen Waldbächen. Oikos 5: 77-93.

OBR, S. 1955. Příspěvek $\mathrm{k}$ studiu fauny jezer a bystřin v Liptovských holých. Acta. Soc. Zool. Bohemoslov. 19: 9-26.

Rabeni, C.F. \& Minshall, G.W. 1977. Factors affecting microdistribution of stream benthic insects. Oikos 29: 33-43.

RichARDSON, J.S. \& MACKAY, R.S. 1991. Lake outlets and the distribution of filter feeders: an assessment of hypotheses. Oikos 62: 370-380.

Sacherová, V., KrŠková, R., Stuchlík, E., HořickÁ, Z., Hudec, I. \& FotT, J. 2006. Long-term change of the littoral Cladocera in the Tatra Mountain lakes through a major acidification event. Biologia, Bratislava 61, Suppl. 18: S109S119.

Stuchlík, E., KopÁČek, J., Fott, J., HořickÁ, Z. \& Veselý, J. 2006. Chemical composition of the Tatra Mountain lakes: Response to acidification. Biologia, Bratislava 61, Suppl. 18: S11-S20.

ŠporkA, F. 1984. Oligochaeta des flusses Belá. Práce Laboratória Rybárstva a Hydrobiológie 4: 99-117.

ŠporkA, F. 1992a. Makrozoobentos mediálu jazier Zápdných Tatier. Zborník TANAP 32: 129-138.

ŠporkA, F. 1992b. Máloštetinavce (Oligochaeta) jazier v Západných Tatrách. Zborník TANAP 32: 139-148.

ŠporkA, F. (ed.) 2003. Vodné bezstavovce (makroevertebráta) Slovenska, súpis druhov a autekologické charakteristiky. Slovenský hydrometerorologický ústav, Bratislava, 590 pp.

Šporka, F., Livingstone, D.M., Stuchlík, E., Turek, J. \& GALAS, J. 2006. Water temperatures and ice cover in lakes of the Tatra Mountains. Biologia, Bratislava 61, Suppl. 18: S77-S90.
ŠTefkovÁ, E. \& ŠporkA, F. 2001. Long-term ecological research of high mountain lakes in the High Tatras (Slovakia). Ekológia, Bratislava 20: 101-106.

TÁtosová, J. \& Stuchlík, E. 2003. Chironomidae (Diptera) profundálu vysokohorských jezer (Vysoké Tatry, Slovensko) v různém stupni acidifikace. Acta Fac. Ecol., Zvolen 10, Suppl. 1: $193-196$.

Ulfstrand, S. 1968. Benthic animal communities in Lapland streams. Oikos, Suppl. 10: 1-120.

VEJdovskÝ, F. 1884. System und Morphologie der Oligochaeten. Praha, 166 pp., 16 plates.

VRAnovský, M., Krno, I., ŠporkA, F. \& TomajkA, J. 1994. The effect of anthropogenic acidification on the hydrofauna of the lakes of the West Tatra Mountains (Slovakia). Hydrobiologia 274: 163-170.

ZAŤOviČOVÁ, Z. 2002. Makrozoobentos Nižného Terianského plesa (Vysoké Tatry). Folia Faunistica Slovaca 7: 19-22.

ZAŤOVIČOVÁ, Z. 2003. Rozdiely v štruktúre bentických spoločenstiev gradientových jazier vo Vysokých Tatrách. Acta Fac. Ecol., Zvolen 10, Suppl. 1: 189-192.

ZAVŘEl, J. 1935a. Chironomidenfauna der Hohen Tatra. Verh. Int. Verein. Theor. Angew. Limnol. 7: 439-448.

ZAVŘEL, J. 1935b. Příspěvek k faune bystřin a jezer ve Vysokých Tatrách. Sbor. Klubu Př́rodověd. Brně 17: 8-12.

ZAVřel, J. 1937a. Eine neue Trissocladiusart. Spisy Př́rodověd. Fak. Masaryk Univ. 239: 3-12.

ZAVŘel, J. 1937b. Orthocladiinae aus der Hohen Tatra. Rev. Ges. Hydrobiol. Hydrograph. 35: 483-496.

ZAVŘEl, J. \& PAGAST, F. 1935. Dva nové druhy Orthocladiin z Vysokých Tater. Čas. Čs. Spol. Entomol. 32: 156-160.

Received July 13, 2005 Accepted May 9, 2006 


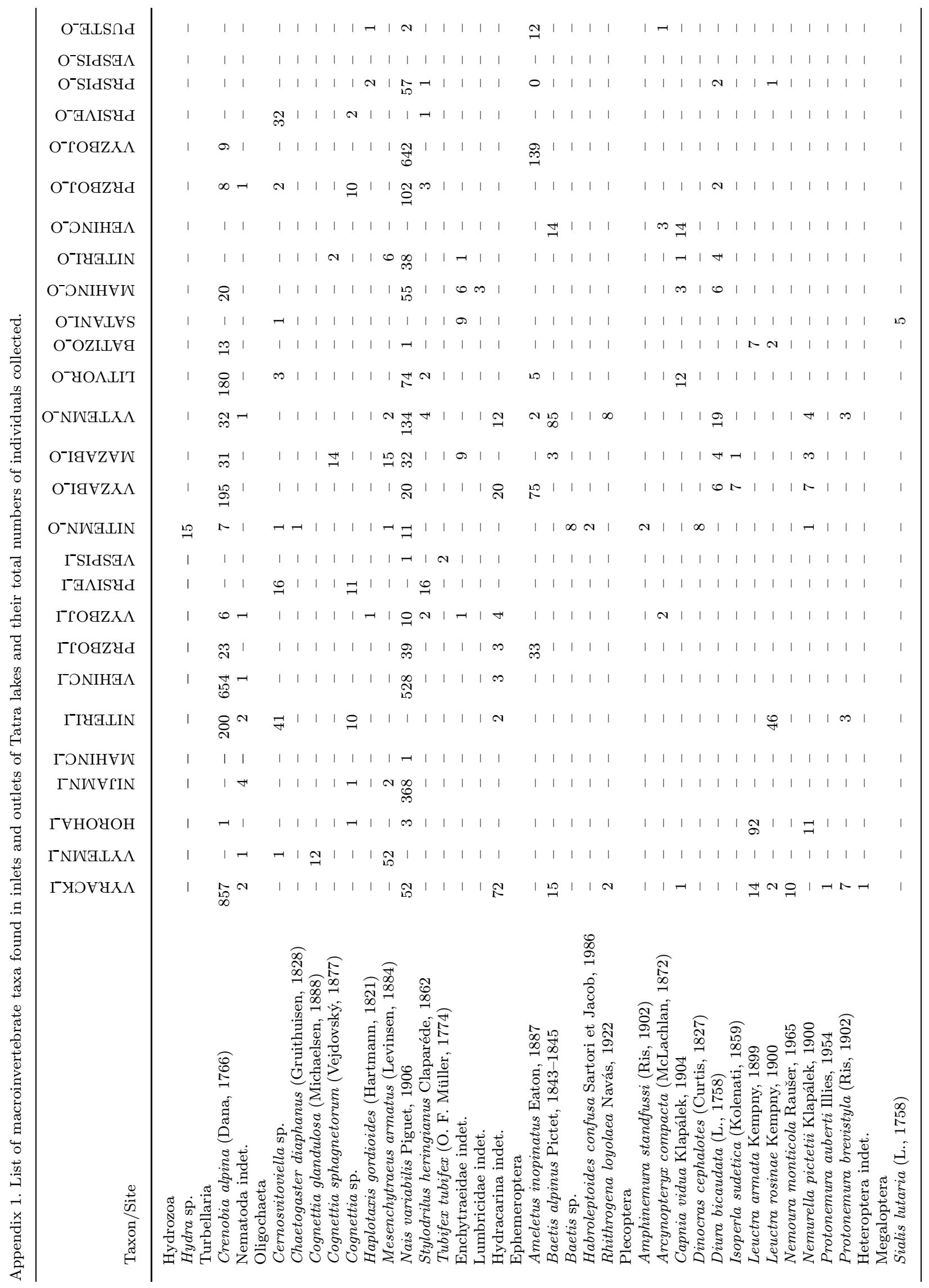




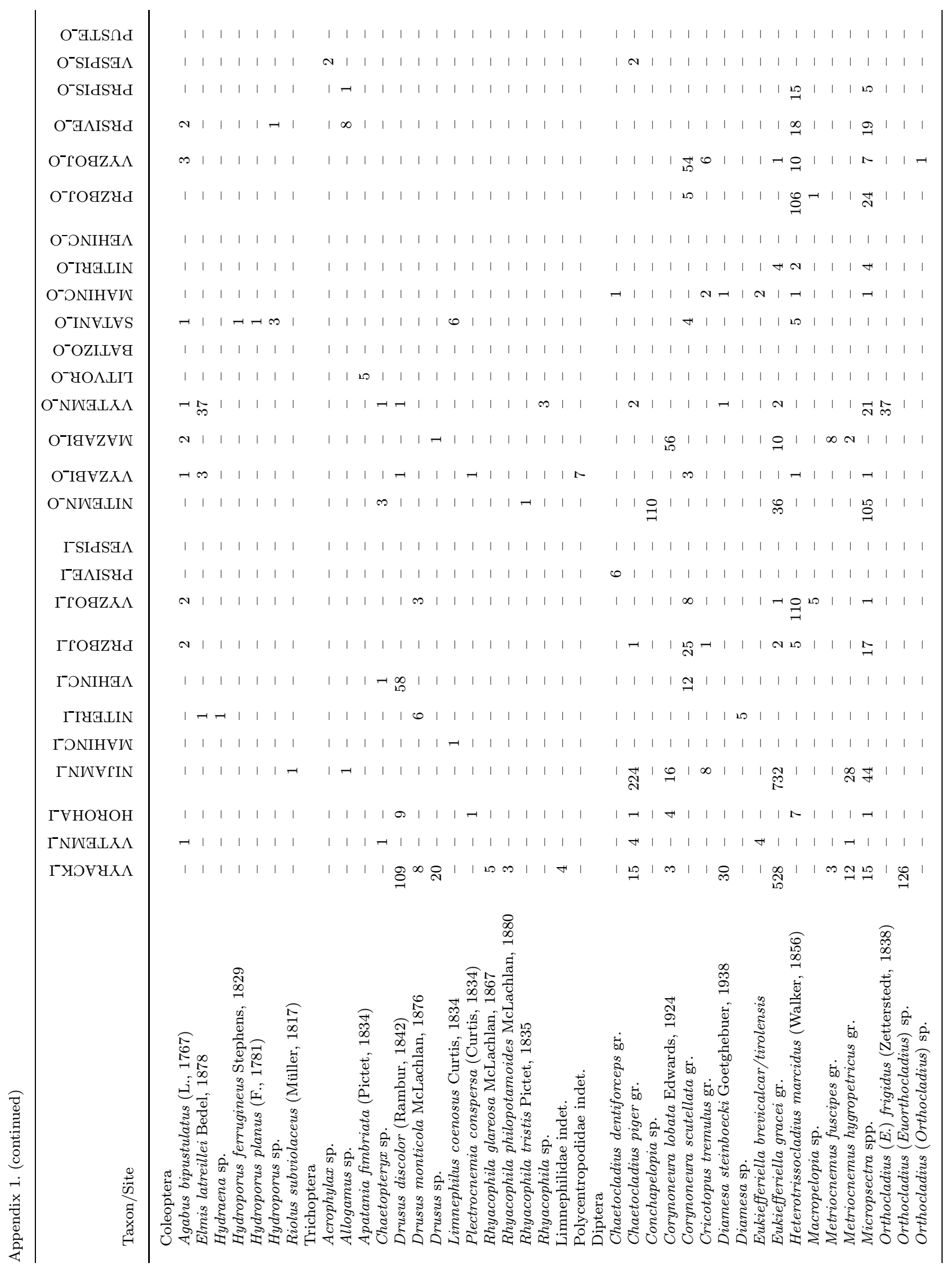




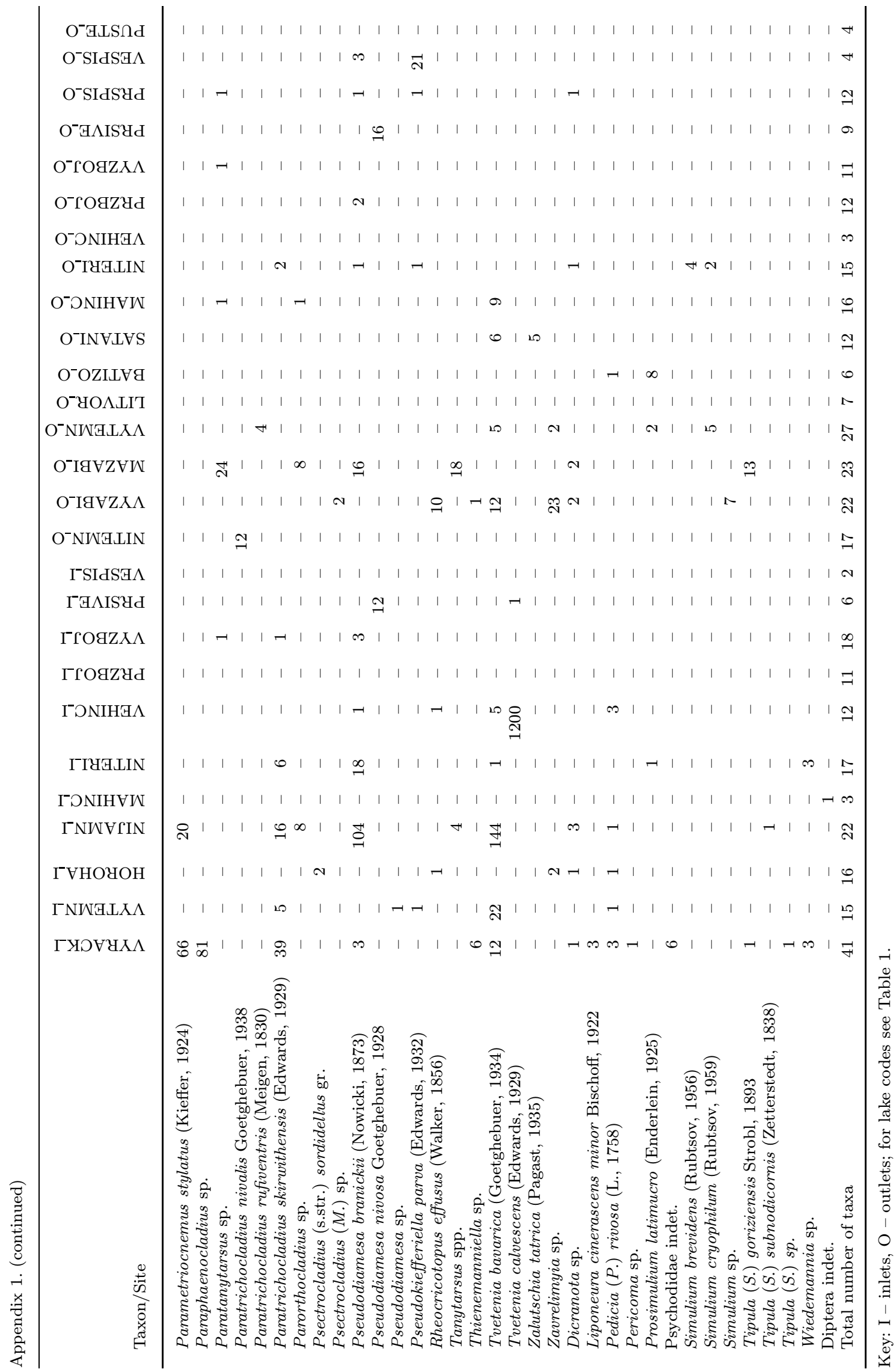

